\title{
Application of System Energy Technology for Renewable Resources*
}

\author{
Yohei KOBAYASHI** and Masaru HIRATA*** \\ ${ }^{* *}$ Research Center for Advanced Technologies, Shibaura Institute of Technology \\ (Now with National Institute of Advanced Industrial Science and Technology) \\ 307 Fukasaku, Minuma-ku, Saitama-si, Saitama 337-8570, Japan \\ E-mail: yohei.kobayashi@aist.go.jp \\ ${ }^{* * *}$ Shibaura Institute of Technology, \\ 3-7-5 Toyosu, Koto-ku, Tokyo, 135-8548 Japan \\ E-mail: president@shibaura-it.ac.jp
}

\begin{abstract}
Renewable energy resources are known to have two critical problems-fluctuation and low density. The authors have already demonstrated the worldwide potential of wind energy within a previous study. In this study, we describe the problem of the fluctuation of renewable resources and its solution. The authors applied "system energy technology" to renewable resources as a relatively long-term solution to the fluctuation problem. System energy technology is a concept for producing new value without new development and it was named by one of the authors of this paper, Prof. Masaru Hirata. This concept is adapted to renewable resources such as a combination of solar and wind energies. The output, which is transformed into hydrogen, is estimated for three different cases $-1 \mathrm{~kW}$ wind turbine, $1 \mathrm{~kW}$ solar cell, and a combination of both in order to study the effect of combining the two resources. The computation is carried out for 840 AMeDAS sites in Japan. The authors observed that the effect of combination is particularly strong in the area along the sea of Japan. In these areas, the monthly fluctuation in the power supply could be reduced by the combined system. On the other hand, the daily output of renewable energy varies. In order to solve this problem, the authors propose that the electric output should be changed to hydrogen. This system is called as the Hythane (hydrogen + methane) pipelines. The authors will discuss the Hythane pipeline systems in the following system study.
\end{abstract}

Key words: Wind Energy, Solar Energy, Natural Energy, Renewable Resources, Hydrogen, Energy Supply, Global Warming

\section{Introduction}

Our society is based on energy consumption, which is necessary for all activities such as those of humans and machines. The activity of society is proportional to its energy consumption, and it appears that an ideal society is equivalent to one that consumes a lot of energy. However, energy should be appropriately consumed based on scientific principles. An energy problem arises due to our over reliance on fossil fuels as an easy source of primary energy. Natural energy is considered to be cleaner than fossil fuels. Natural energy, except geothermal energy, originates from the sun, and it is converted into useful forms of energy such as electricity using wind turbines, solar cells, etc. The overall energy balance on the earth is maintained since surplus energy is emitted from the earth in the form of radiation. The greatest energy source is the sun, which is external to the earth. This implies 
that it can avoid increasing the entropy of the earth by using natural resources. In other words, it increases the amount of energy on the earth. We do not harness such a useful natural energy source because it has a low energy density as compared to that of conventional power conversion technology and it is irregular/unstable (it has fluctuations). To use natural energy, it is necessary to improve its unstable characteristics; it is expected that this problem will be solved by using system energy technology. Therefore, the authors considered the application of system energy technology to natural resources. The system energy technology application is defined as follows: produce a new value without the need for new technological developments. We attempted to apply this method to a combination of wind and solar energy. In addition, an output in the form of electricity usually cannot be stored in large amounts; however, it can be stored in large amounts in the form of hydrogen since hydrogen is a physical material.

There are some fluctuation periods for renewable resources, mainly seasonal and daily periods. It is generally difficult to solve the seasonal fluctuation problem using hydrogen because natural energy does not harness an adequate amount of outputs and it is infeasible to install such large hydrogen storage tanks. Therefore, we propose the use of the system energy technology to address the seasonal fluctuations and hydrogen storage to address the daily fluctuations. Further, this hydrogen energy storage could be potentially useful for fuel cell applications in the future. In this study, we computed the electricity output from wind turbines, solar cells, and a combination of these from the data for the last ten years recorded from 840 AMeDAS observation sites; we could clarify the effectiveness of the system energy technology for the case of combination of wind and solar energy.

\title{
Nomenclature
}

\author{
$P_{R}:$ Rated Output \\ $V_{I}$ : Cut- in wind velocity \\ $V_{R}:$ Wind velocity at rated output \\ $V_{O}$ : Cut-out wind velocity \\ $H_{T}$ : Total amount of solar radiation \\ $H_{D}$ : Direct solar radiation \\ $H_{S}:$ Sky solar radiation \\ $H_{R}$ : Reflectional solar radiation \\ AMeDAS: Automated Meteorological Data Acquisition System
}

\section{Computational setup}

\subsection{Wind power}

In this calculation, we assumed a small wind turbine whose output performance curve is shown in figure 1 . The performance parameters of the wind turbine are listed below.

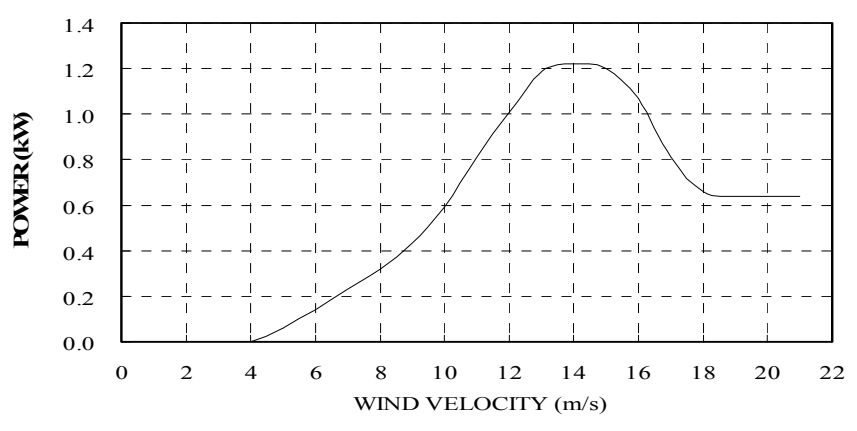

$\mathrm{P}_{\mathrm{R}}=1000[\mathrm{~W}], \mathrm{V}_{\mathrm{I}}=3[\mathrm{~m} / \mathrm{s}], \mathrm{V}_{\mathrm{R}}=11[\mathrm{~m} / \mathrm{s}], \mathrm{V}_{\mathrm{O}}=20[\mathrm{~m} / \mathrm{s}]$

Fig.1 Power Curve for a Small Wind Turbine 
In our calculations, the change in the wind direction is not considered within calculation. Wind continuously changes not only in speed but also in direction. However, the authors considered that a propeller-type windmill is used for measuring the wind velocity at an AMeDAS observation site, and the change in the wind direction should be incorporated into the wind velocity measurement. The observation data are given in terms of the averaged wind velocity per hour. The output is obtained by using these wind velocity and power curve.

\subsection{Solar power}

Sunlight comprises the total amount of solar radiation- i.e. direct solar radiation, sky solar radiation, and reflectional solar radiation. The total amount of solar radiation is represented by equation (1).

where

$$
\mathrm{H}_{\mathrm{T}}=\mathrm{H}_{\mathrm{D}}+\mathrm{H}_{\mathrm{S}}+\mathrm{H}_{\mathrm{R}} \ldots(1)
$$

$\mathrm{H}_{\mathrm{T}}$ : Total amount of solar radiation $\left[\mathrm{J} /\left(\mathrm{m}^{2} \mathrm{~h}\right)\right]$

$\mathrm{H}_{\mathrm{D}}$ : Direct solar radiation $\left[\mathrm{J} /\left(\mathrm{m}^{2} \mathrm{~h}\right)\right]$

$\mathrm{H}_{\mathrm{S}}$ : Sky solar radiation $\left[\mathrm{J} /\left(\mathrm{m}^{2} \mathrm{~h}\right)\right]$

$\mathrm{H}_{\mathrm{R}}$ : Reflectional solar radiation $\left[\mathrm{J} /\left(\mathrm{m}^{2} \mathrm{~h}\right)\right]$

In order to calculate the radiation incident on a tilted panel, the following three parameters should be determined.

(1) T: Panel tilt angle

(2) $\quad \alpha$ : Panel azimuthal angle

(3) $\rho_{\mathrm{G}}$ : Ground reflectance

(where : $\rho_{\mathrm{G}}$ can be ignored since it is $3 \sim 5 \%$ of the total amount of horizontally incident solar radiation.)

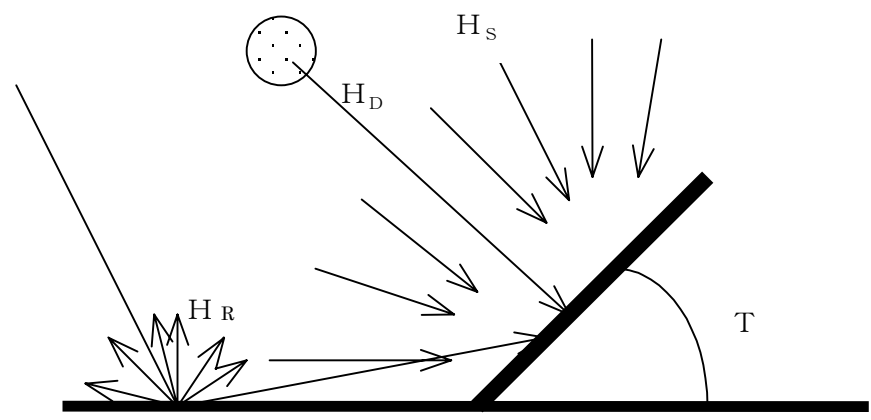

Plane View

Fig.2 Inclined Solar Radiation

In this study, the authors avoided giving the most suitable panel tilt angle about 840 places of AMeDAS observation spots, and the solar cell panel is assumed to be flat (horizontal). As per this assumption, the influence of energy generation would be around $20 \%$ underestimate as shown in Fig. 3 . The authors considered that the $20 \%$ underestimate should be included in our fundamental study.

We assumed that it is necessary for the solar cell panel to have an area of $10\left[\mathrm{~m}^{2}\right]$ when it is horizontal. For this area, the output rating would be around $1 \mathrm{~kW}$, which would balance the $1 \mathrm{~kW}$ wind turbine that we assumed. In our calculations, we assumed an amorphous silicon solar cell whose efficiency is around $10 \%$. Generally, the efficiency of a solar cell does not change with scale (large or small). Therefore, under ideal weather conditions, when $1[\mathrm{~kW}]$ is incident on $1\left[\mathrm{~m}^{2}\right]$, the output of a solar cell with $10[\%]$ efficiency is 100 $[\mathrm{W}]$ per $1\left[\mathrm{~m}^{2}\right]$. In other words, under ideal weather conditions, an output of $1[\mathrm{~kW}]$ will be harnessed in a $10\left[\mathrm{~m}^{2}\right]$ area. 


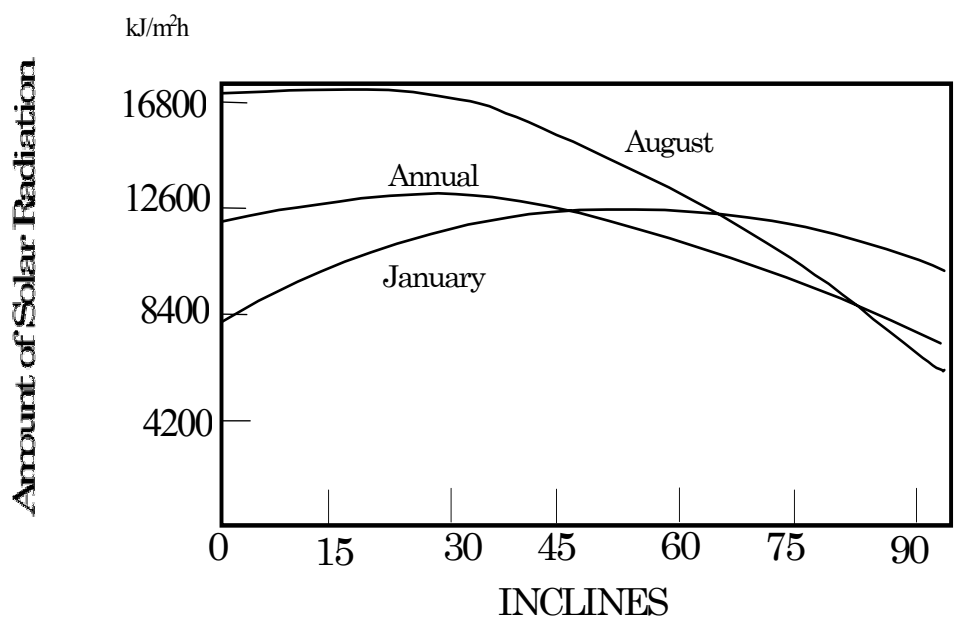

Fig.3 Dependence of the Amount of Solar Radiation on the Panel Angle

\subsection{Hydrogen}

The amount of electric energy that is required to obtain one cubic meter of hydrogen is called as the hydrogen energy basic unit. In this study, the authors employed a proton-exchange-membrane-type electrolyzer. This type of electrolyzer is expected to be mass-produced in the near future, and it will function as a fuel cell for home cogeneration systems. A proton-exchange-membrane-type fuel cell provides a functionality that is the exact opposite of that of an electrolysis device. The hydrogen energy basic unit of this type of fuel cell is calculated in this study as $6.8\left[\mathrm{kWh} / \mathrm{m}^{3}\right]$.

\section{Procedure}

The authors define a value called "total annual deviation," examples of which are shown in the figure below. We subtracted the monthly output from the annual average and if each monthly output is equal, then the final value becomes zero. If this value is large, it implies that the output fluctuation is large. We performed this calculation for the wind turbine output, solar cell output, and the output for the combined case. The combined system is considered to be effective at an observation point when it satisfies the following relation:

Total independent deviation $>$ total deviation in the combined system

An observation point that shows a large difference is considered to be a highly effective area for the combined system. Therefore, this difference is defined as the index of the combined system.

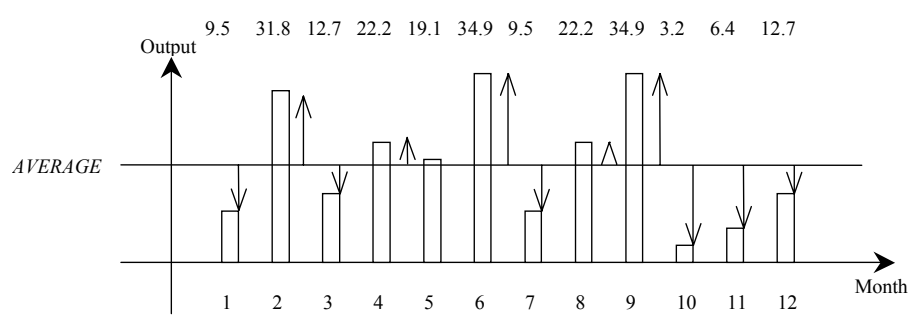

Fig.4 Monthly Electricity Generation and its Deviation

\section{Results and Discussions}

The computational results are shown by using several tables and figures. Parties interested in obtaining these results can contact the authors. 


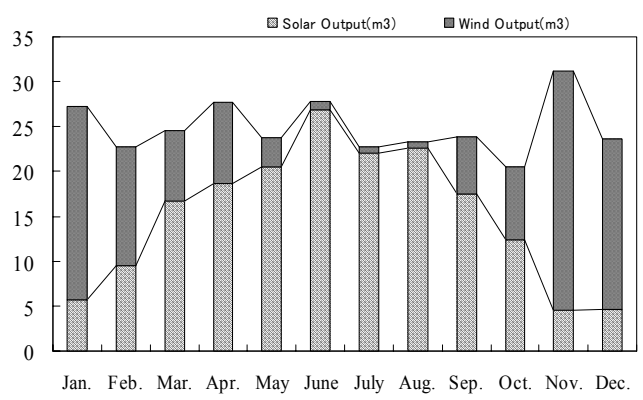

Hokkaido Kamoenai 1986

\begin{tabular}{|l|r|r|r|r|r|r|r|r|r|r|r|r|r|}
\hline & Jan. & Feb. & Mar. & Apr. & May & June & July & Aug. & Sep. & Oct. & Nov. & Dec. & Total \\
\hline Solar Output $\left(\mathrm{m}^{3}\right)$ & 6 & 9 & 17 & 19 & 21 & 27 & 22 & 23 & 18 & 12 & 4 & 5 & 182 \\
\hline Wind Output $\left(\mathrm{m}^{3}\right)$ & 21 & 13 & 8 & 9 & 3 & 1 & 1 & 1 & 6 & 8 & 27 & 19 & 117 \\
\hline Total Output $\left(\mathrm{m}^{3}\right)$ & 27 & 23 & 25 & 28 & 24 & 28 & 23 & 23 & 24 & 21 & 31 & 24 & 299 \\
\hline
\end{tabular}

Fig.5 Monthly Combined Effect (Kamoenai)

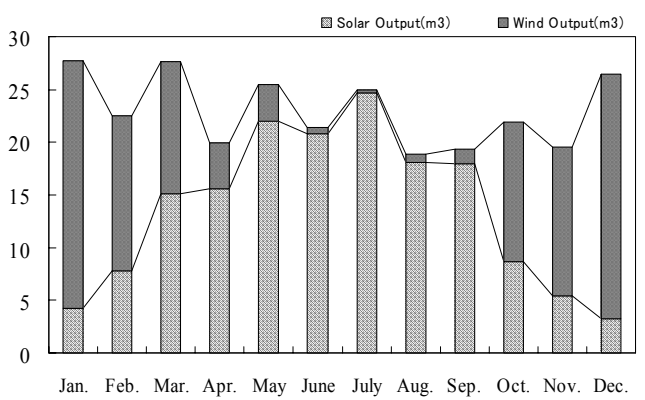

Hokkaido Shosanbetu 1988

\begin{tabular}{|l|r|r|r|r|r|r|r|r|r|r|r|r|r|}
\hline & Jan. & Feb. & Mar. & Apr. & May & June & July & Aug. & Sep. & Oct. & Nov. & Dec. & Total \\
\hline Solar Output $\left(\mathrm{m}^{3}\right)$ & 4 & 8 & 15 & 16 & 22 & 21 & 25 & 18 & 18 & 9 & 5 & 3 & 163 \\
\hline Wind Output $\left(\mathrm{m}^{3}\right)$ & 24 & 15 & 13 & 4 & 3 & 1 & 0 & 1 & 1 & 13 & 14 & 23 & 112 \\
\hline Total Output $\left(\mathrm{m}^{3}\right)$ & 27 & 23 & 25 & 28 & 24 & 28 & 23 & 23 & 24 & 21 & 31 & 24 & 276 \\
\hline
\end{tabular}

Fig.6 Monthly Combined Effect (Shosanbetu)

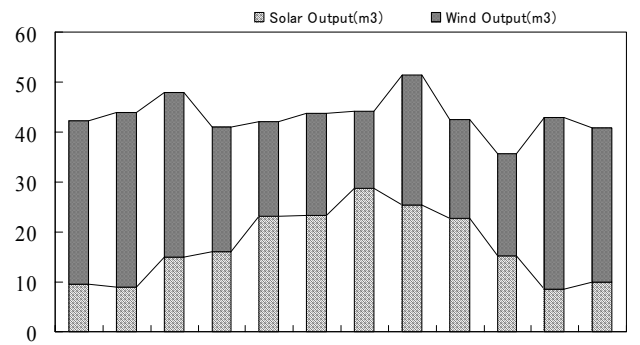

Jan. Feb. Mar. Apr. May June July Aug. Sep. Oct. Nov. Dec.

\begin{tabular}{|l|r|r|r|r|r|r|r|r|r|r|r|r|r|}
\hline & Jan. & Feb. & Mar. & Apr. & May & June & July & Aug. & Sep. & Oct. & Nov. & Dec. & Total \\
\hline Solar Output $\left(\mathrm{m}^{3}\right)$ & 9 & 9 & 15 & 16 & 23 & 23 & 29 & 25 & 23 & 15 & 8 & 10 & 207 \\
\hline Wind Output $\left(\mathrm{m}^{3}\right)$ & 33 & 35 & 33 & 25 & 19 & 20 & 16 & 26 & 20 & 20 & 35 & 31 & 312 \\
\hline Total Output $\left(\mathrm{m}^{3}\right)$ & 42 & 44 & 48 & 41 & 42 & 44 & 44 & 51 & 43 & 36 & 43 & 41 & 518 \\
\hline
\end{tabular}

Fig.7 Monthly Combined Effect (Okinoerabu) 


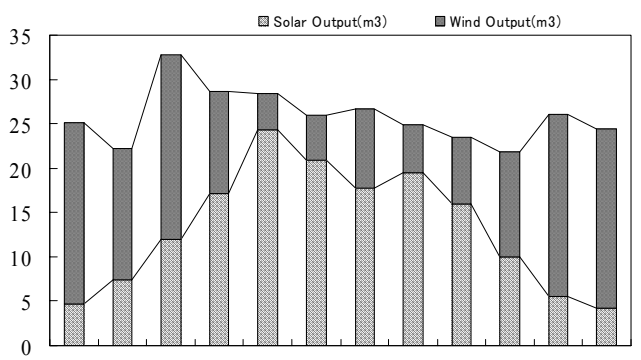

Jan. Feb. Mar. Apr. May June July Aug. Sep. Oct. Nov. Dec.

Hokkaido Setana 1991

\begin{tabular}{|l|r|r|r|r|r|r|r|r|r|r|r|r|r|}
\hline & Jan. & Feb. & Mar. & Apr. & May & June & July & Aug. & Sep. & Oct. & Nov. & Dec. & Total \\
\hline Solar Output $\left(\mathrm{m}^{3}\right)$ & 5 & 7 & 12 & 17 & 24 & 21 & 18 & 20 & 16 & 10 & 6 & 4 & 159 \\
\hline Wind Output $\left(\mathrm{m}^{3}\right)$ & 20 & 15 & 21 & 11 & 4 & 5 & 9 & 5 & 8 & 12 & 21 & 20 & 151 \\
\hline Total Output $\left(\mathrm{m}^{3}\right)$ & 25 & 22 & 33 & 29 & 28 & 26 & 27 & 25 & 24 & 22 & 26 & 24 & 310 \\
\hline
\end{tabular}

Fig.8 Monthly Combined Effect (Setana)

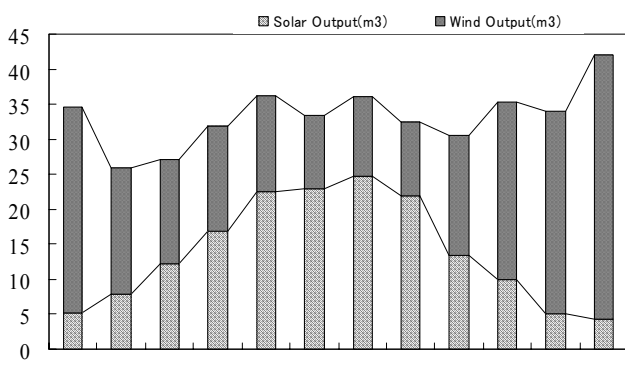

Jan. Feb. Mar. Apr. May June July Aug. Sep. Oct. Nov. Dec.

Hokkaido Rumoi 1989

\begin{tabular}{|l|r|r|r|r|r|r|r|r|r|r|r|r|r|}
\hline & \multicolumn{1}{|c|}{ Jan. } & Feb. & Mar. & Apr. & May & June & July & Aug. & Sep. & Oct. & Nov. & Dec. & Total \\
\hline Solar Output $\left(\mathrm{m}^{3}\right)$ & 5 & 8 & 12 & 17 & 23 & 23 & 25 & 22 & 13 & 10 & 5 & 4 & 167 \\
\hline Wind Output $\left(\mathrm{m}^{3}\right)$ & 29 & 18 & 15 & 15 & 14 & 11 & 11 & 11 & 17 & 25 & 29 & 38 & 233 \\
\hline Total Output $\left(\mathrm{m}^{3}\right)$ & 34 & 26 & 27 & 32 & 36 & 33 & 36 & 32 & 31 & 35 & 34 & 42 & 400 \\
\hline
\end{tabular}

Fig.9 Monthly Combined Effect (Rumoi)

Table 1 List of Approved Points in 1994

\begin{tabular}{|c|c|c|c|}
\hline PREFECTURE & PLACE & YEAR & INDEX \\
\hline HOKKAIDO & KAMOENAI & 1994 & 226 \\
\hline HOKKAIDO & ENBETU & 1994 & 208 \\
\hline YAMAGATA & SAKATA & 1994 & 179 \\
\hline TOKYO & MIYAKEJIMA & 1994 & 168 \\
\hline HOKKAIDO & ATUTA & 1994 & 152 \\
\hline CHIBA & CHOSI & 1994 & 147 \\
\hline HOKKAIDO & RUMOI & 1994 & 144 \\
\hline SHIZUOKA & ISHIROUZAKI & 1994 & 130 \\
\hline HOKKAIDO & SYOSANBETU & 1994 & 121 \\
\hline KYOTO & TAIZA & 1994 & 116 \\
\hline AKITA & KUTUGATA & 1994 & 114 \\
\hline HOKKAIDO & HABORO & 1994 & 113 \\
\hline HOKKAIDO & SETANA & 1994 & 104 \\
\hline TOKYO & OOSHIMA & 1994 & 101 \\
\hline AKITA & NOSIRO & 1994 & 98 \\
\hline HOKKAIDO & FUNADOMARI & 1994 & 92 \\
\hline HOKKAIDO & MURORAN & 1994 & 83 \\
\hline HOKKAIDO & HAMAMASU & 1994 & 79 \\
\hline HOKKAIDO & KUTUGATA & 1994 & 75 \\
\hline ISHIKAWA & HAKUISHI & 1994 & 49 \\
\hline ISHIKAWA & KANAZAWA & 1994 & 48 \\
\hline AKITA & AKITA & 1994 & 45 \\
\hline AKITA & HACHIMORI & 1994 & 28 \\
\hline KAGOSHIMA & YAKUSHIMA & 1994 & 20 \\
\hline IBARAKI & TUKUBASAN & 1994 & 19 \\
\hline SHIZUOKA & MATUZAKI & 1994 & 18 \\
\hline TOYAMA & TOMARI & 1994 & 16 \\
\hline & & & \\
\hline
\end{tabular}


Instead of showing all the calculated results, we only show the complete count for ten years. Table 2 shows the 20 highest ranking observation points for a complete count. According to table 2, the results indicate a variation in the potential of the combined system in each prefecture. The authors determine the potential for each prefecture in the next expression. Through this sorting, the potential of the combined system in Hokkaido prefecture was verified. Other characteristics indicate a high mutual supplemental effect in a prefecture near the sea shore of Japan. Figure 10 shows the potential of the total system in each prefecture. Figure 11 shows the potential of each prefecture on the map. Figure 12 shows the results shown in Table 2 on the map.

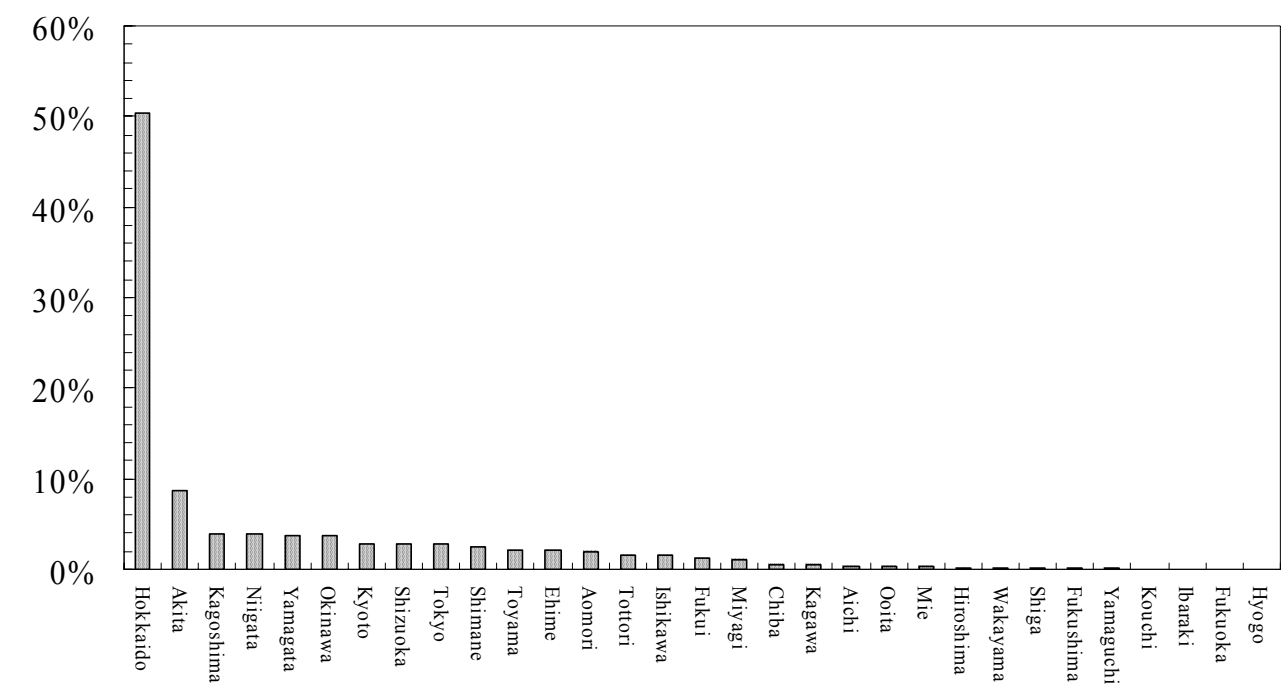

Fig.10 Potential of Combined Power in Each Prefecture

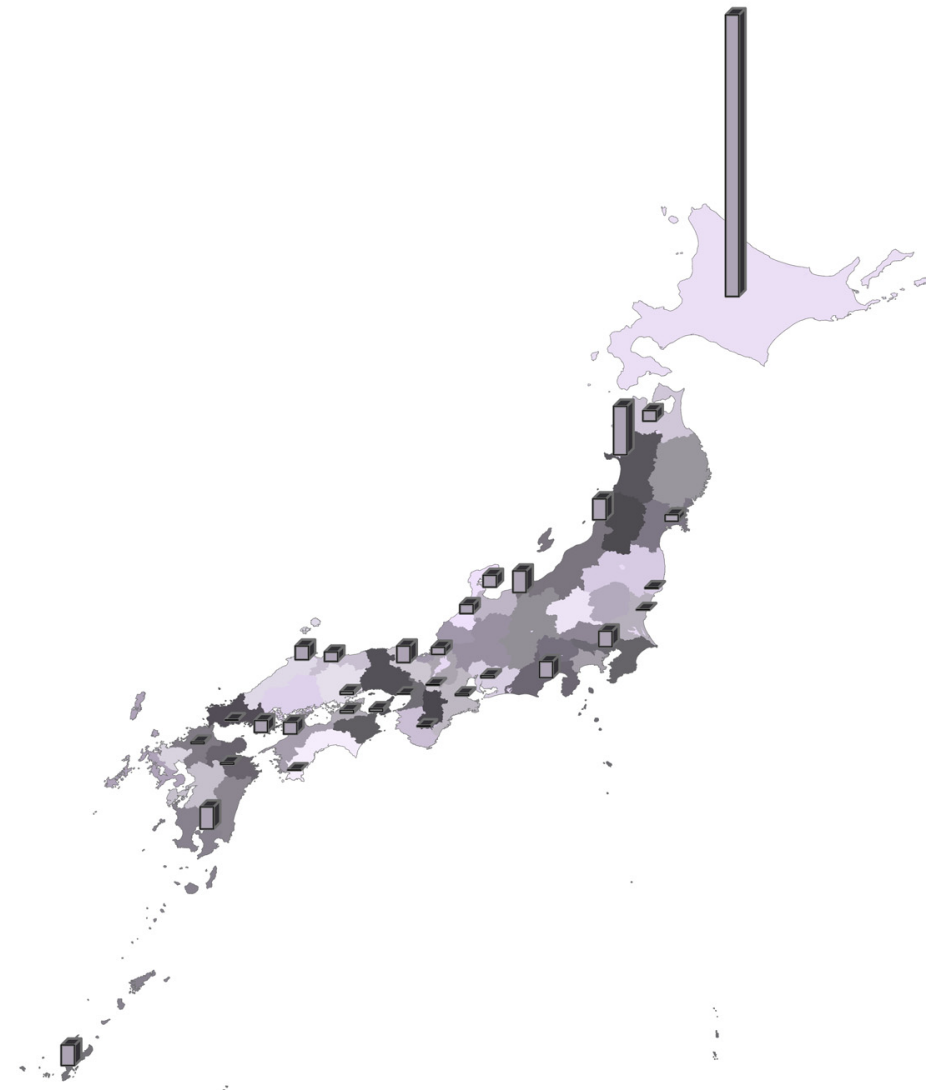

Fig.11 Potential of Combined Power in Each Prefecture 
Table 2 Observation Points with Highest Potential

\begin{tabular}{|c|c|c|c|}
\hline RANK & PREFECTURE & PLACE & INDEX \\
\hline 1 & HOKKAIDO & KAMOENAI & 2340 \\
\hline 2 & HOKKAIDO & SETANA & 1850 \\
\hline 3 & HOKKAIDO & KUTUKATA & 1488 \\
\hline 4 & HOKKAIDO & SYOSANBETU & 1433 \\
\hline 5 & HOKKAIDO & HABORO & 1308 \\
\hline 6 & AKITA & NOSIRO & 1286 \\
\hline 7 & HOKKAIDO & ENBETU & 1189 \\
\hline 8 & HOKKAIDO & ATUTA & 1119 \\
\hline 9 & YAMAGATA & SAKATA & 1099 \\
\hline 10 & HOKKAIDO & RUMOI & 1090 \\
\hline 11 & HOKKAIDO & HAMAMASU & 984 \\
\hline 12 & KYOTO & TAIZA & 945 \\
\hline 13 & HOKKAIDO & FUNADOMARI & 743 \\
\hline 14 & TOYAMA & TOMARI & 685 \\
\hline 15 & NIIGATA & NIIGATA & 672 \\
\hline 16 & HOKKAIDO & MATUMAE & 639 \\
\hline 17 & KAGOSIMA & OKINOERABU & 628 \\
\hline 18 & SIMANE & HAMADA & 596 \\
\hline 19 & AKITA & AKITA & 588 \\
\hline 20 & HOKKAIDO & MURORAN & 583 \\
\hline
\end{tabular}

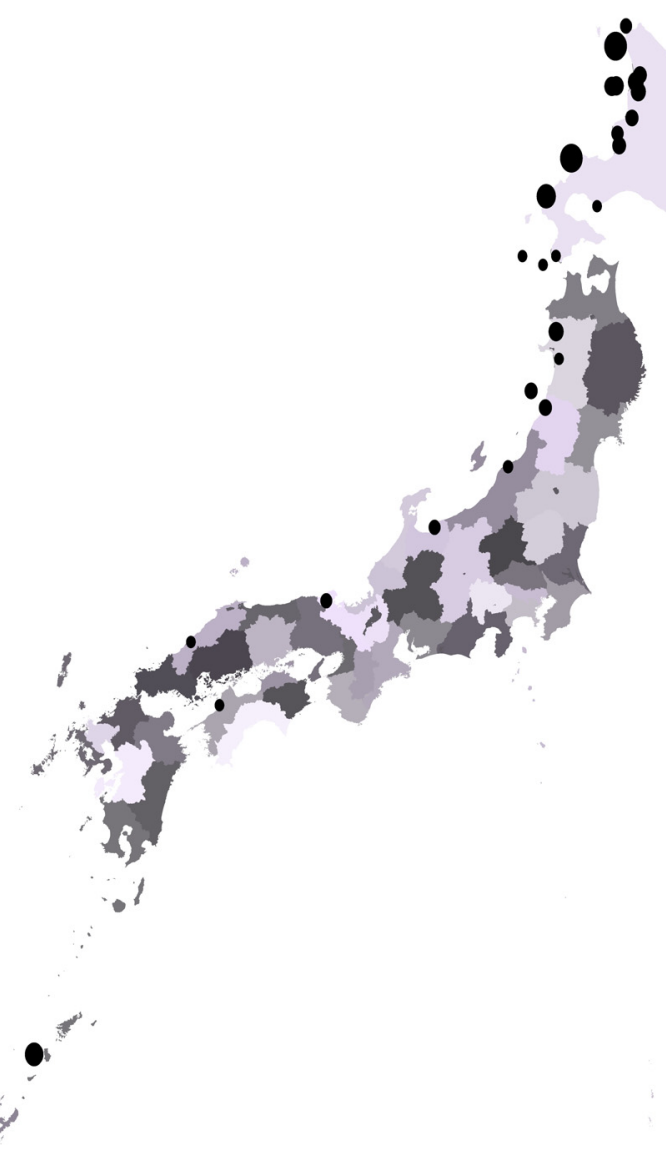

Fig.12 Observation Points with Highest Potential 


\section{Conclusions}

Based on weather data, the authors computed the effectiveness of the application of system energy technology to wind and solar energy.

(1) The system energy technology can be effectively applied to wind and solar energy in some regions.

(2) The effective region is the Hokkaido prefecture.

(3) The effective area is distributed along the sea shore of Japan.

(4) In these areas, the number of hydrogen storage tanks should be significantly reduced by using system energy technology.

\section{Acknowledgement}

We received substantial support from the Asia Pipeline Research Center in the Shibaura Institute of Technology in accomplishing this study. In addition, Dr. Ushiyama of the Ashikaga Institute of Technology provided us with valuable advice. The authors express their sincerely thanks to these contributors.

\section{References}

(1) Masaru HIRTA, Fundamental Concept of Energy Conservation, Ohm, (1994), pp31 34. (in Japanese)

(2) OM Meteorological data, (1985 1994)、OM Research Institute

(3) Solar Energy Handbook, (1985), (10)(43)(50), Japan Solar Energy Society (in Japanese)

(4) Yohei KOBAYASHI, Masaru HIRATA, "ESTIMATION OF WIND RESOURCES THROUGHOUT THE WORLD” Heat Transfer Asian Research Volume 34, Issue 5 (2005) 